\title{
Probiotic Administration Increases Amino Acid Absorption from Plant Protein: a Placebo-Controlled, Randomized, Double-Blind, Multicenter, Crossover Study
}

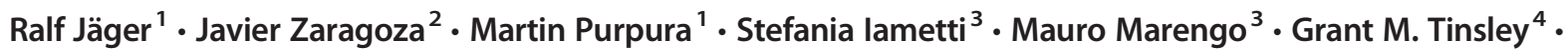 \\ Anthony J. Anzalone ${ }^{5} \cdot$ Jonathan M. Oliver $^{6} \cdot$ Walter Fiore $^{7} \cdot$ Andrea Biffi $^{7} \cdot$ Stacie Urbina $^{2} \cdot$ Lem Taylor $^{2}$
}

(C) The Author(s) 2020

\begin{abstract}
The fate of dietary protein in the gut is determined by microbial and host digestion and utilization. Fermentation of proteins generates bioactive molecules that have wide-ranging health effects on the host. The type of protein can affect amino acid absorption, with animal proteins generally being more efficiently absorbed compared with plant proteins. In contrast to animal proteins, most plant proteins, such as pea protein, are incomplete proteins. Pea protein is low in methionine and contains lower amounts of branched-chain amino acids (BCAAs), which play a crucial role in muscle health. We hypothesized that probiotic supplementation results in favorable changes in the gut microbiota, aiding the absorption of amino acids from plant proteins by the host. Fifteen physically active men $(24.2 \pm 5.0$ years; $85.3 \pm 12.9 \mathrm{~kg} ; 178.0 \pm 7.6 \mathrm{~cm} ; 16.7 \pm 5.8 \%$ body fat) co-ingested $20 \mathrm{~g}$ of pea protein with either AminoAlta ${ }^{\mathrm{TM}}$, a multi-strain probiotic (5 billion CFU L. paracasei LP-DG® (CNCM I-1572) plus 5 billion CFU L. paracasei LPCS01 (DSM 26760), SOFAR S.p.A., Italy) or a placebo for 2 weeks in a randomized, double-blind, crossover design, separated by a 4-week washout period. Blood samples were taken at baseline and at 30-, 60-, 120-, and 180-min post-ingestion and analyzed for amino acid content. Probiotic administration significantly increased methionine, histidine, valine, leucine, isoleucine, tyrosine, total BCAA, and total EAA maximum concentrations (Cmax) and AUC without significantly changing the time to reach maximum concentrations. Probiotic supplementation can be an important nutritional strategy to improve post-prandial changes in blood amino acids and to overcome compositional shortcomings of plant proteins. ClinicalTrials.gov Identifier: ISRCTN38903788
\end{abstract}

Keywords Protein · Probiotic $\cdot$ Amino acid absorption $\cdot$ Muscle health

Ralf Jäger

ralf.jaeger@ increnovo.com

1 Increnovo, Milwaukee, WI, USA

2 Human Performance Laboratory, School of Exercise \& Sport Science, University of Mary Hardin-Baylor, Belton, TX, USA

3 Department of Food, Environmental and Nutritional Sciences (DeFENS), Università degli Studi di Milano, Milan, Italy

4 Energy Balance \& Body Composition Laboratory, Texas Tech University, Lubbock, TX, USA

5 Wake Forest School of Medicine, Winston-Salem, NC, USA

6 Army West Point Athletics Association, West Point, NY, USA

7 Sofar S.p.A., Trezzano Rosa, Italy

\section{Introduction}

Lactobacillus paracasei strains have been isolated from the intestinal and reproductive tracts of humans and animals and numerous food products such as raw milk, plants, or fermented foods [1]. There are currently no clinical trials on the combination of $L$. paracasei LP-DG® and L. paracase $i$ LPC-S01; however, the individual strains have been studied for various health applications. Probiotic L paracasei LPDG® (CNCM I-1572) can survive gastrointestinal transit in children [2] and healthy adults [3] and has been shown to be able to modulate gut microbiota structure/function and immune health in healthy adults [4], patients with irritable bowel syndrome (IBS) [5, 6], and diverticular disease [7-10]. Similar to L. paracasei LP-DG® (CNCM I-1572), L. paracasei LPCS01 (DSM 26760) has been shown to colonize the human gut of healthy adults [11]. Through optimizing gut microbiota 
composition, probiotics have been linked to improve nutrient absorption, including protein utilization [12].

Different types and quality of dietary protein can affect amino acid absorption following protein supplementation. Compared with animal protein sources, plant protein sources, with the exception of soy protein, are incomplete proteins lacking in one or more essential amino acids. Plant proteins contain less branched-chain amino acids (BCAAs), especially leucine [13], one of the crucial amino acids for muscle health, especially the activation of muscle protein synthesis (MPS) [14]. In addition, plant proteins differ in absorption kinetics and the amount of amino acids absorbed by the host. Therefore, there is an interest in nutritional strategies to raise the blood amino acid concentrations after ingesting a plant protein source to overcome compositional shortcomings.

The fate of dietary protein in the gut is determined by microbial and host digestion and utilization. Dietary protein is cleaved into polypeptides by proteases at low $\mathrm{pH}$ in the stomach. Further degradation in the intestine by luminal proteases and membrane bound peptidases results in the formation of peptides and amino acids. Amino acids enter the cell via various transmembrane transport proteins, amino acid transporters, while di- and tripeptides are absorbed into the intestinal cells via the mammalian proton-coupled peptide transporter PEPT1. In the cytosol, peptides are mostly degraded leaving the cell as amino acids. Bacterial proteolytic fermentation in the gut competes with host digestion, significantly contributing to the metabolite pool in the large intestine and contributing to host amino acid balance in the small intestine. Microbial protein fermentation alters the gut microbiota composition and generates a diverse range of bioactive molecules which exert wide-ranging host effects [15].

While lactic acid bacteria (LAB) have proteases and peptidases that provide the bacteria with free amino acids for optimal growth, they are not classified as strongly proteolytic bacteria. The role of LAB such as L. paracasei on protein digestion and absorption of amino acids by the host is currently unknown.

The purpose of this study was to investigate the individual and potential additive or synergistic effects of $L$. paracasei LP-DG® (CNCM I-1572) and/or L. paracasei LPC-S01 (DSM 26760) on the in vitro digestion of different plant protein sources, followed by a human study investigating blood amino acid concentrations after co-administration of plant protein and probiotics.

\section{Materials and Methods}

\section{In Vitro Tests}

In vitro proteolytic effects of the two probiotic strains towards different plant protein sources have been investigated by incubating suspensions of either pea or rice protein isolates with the probiotic bacterial strains, in the presence and in the absence of porcine pepsin (EC 3.4.23.1; Sigma-Aldrich, Milan, Italy) and pancreatin (Sigma-Aldrich, Milan, Italy). In particular, $0.8 \mathrm{~mL}$ of protein isolate suspension $(10 \mathrm{~g} / \mathrm{L})$ was mixed with $0.02 \mathrm{~mL}$ of porcine gastric pepsin solution $(2 \mathrm{~g} / \mathrm{L}$ in water). After $1-\mathrm{h}$ incubation at $37{ }^{\circ} \mathrm{C}$ under mixing, the $\mathrm{pH}$ was adjusted to $\approx 8.0$ by adding $1 \mathrm{M}$ Tris base, and $0.2 \mathrm{~mL}$ pancreatin from porcine pancreas $(2 \mathrm{~g} / \mathrm{L}$ in 0.1 M Tris-HCl buffer, pH 7.5; EC 232-468-9) were added. Pancreatin digestion was carried out for $3 \mathrm{~h}$ in the absence or in the presence (when appropriate) of $0.1 \mathrm{~mL}$ of probiotic cells $(250 \mathrm{~g} / \mathrm{L}$ in $0.1 \mathrm{M}$ Tris- $\mathrm{HCl}$ buffer, $\mathrm{pH}$ 7.5). To address the proteolytic activity of the bacteria alone on the various substrates, reaction mixtures were prepared by using the probiotic strains either individually or in combination, but without adding any proteases. Also, as a negative control, $0.1 \mathrm{~mL}$ bacterial cell suspensions were mixed with $0.1 \mathrm{M}$ Tris- $\mathrm{HCl}$ buffer, $\mathrm{pH}$ 7.5 .

Peptides released upon proteolysis in all tested conditions were assessed by adding to an appropriate aliquot of each reaction mixture trichloroacetic acid (TCA) up to a final $10 \%$ amount. After centrifuging at $10000 \times g$ for $25 \mathrm{~min}$ at room temperature, the absorbance at $280 \mathrm{~nm}$ of the supernatant provides the amount of soluble peptides.

For SDS-PAGE analysis, adequate amounts of the different reaction mixtures at various times of incubation were diluted (1/1, v/v) with Laemmli denaturing buffer ( $0.125 \mathrm{M}$ Tris-HCl, pH 6.8; 50\% glycerol; $1.7 \%$ SDS; $0.01 \%$ bromophenol blue; $1 \%$ 2-mercaptoethanol) and heated at $100{ }^{\circ} \mathrm{C}$ for $10 \mathrm{~min}$. SDS-PAGE was carried out on a $12 \%$ monomer gel, by using a MiniProtein apparatus (Bio-Rad, Richmond, VA, USA), and gels were Coomassie Blue-stained.

Aliquots of the various reaction mixtures were treated with $0.1 \%$ trifluoroacetic acid (TFA) and subsequently centrifuged at $12000 \times \mathrm{g}$ for $20 \mathrm{~min}$. A $0.2 \mathrm{~mL}$ aliquot of the soluble material was loaded onto a Symmetry C18 column $(300 \AA ; 3.5 \mu \mathrm{m} ; 2.1 \mathrm{~mm} \times 50 \mathrm{~mm}$; Waters, Milan, IT), previously equilibrated with $0.1 \%$ TFA in distilled water, and eluted at a flow rate of $0.8 \mathrm{~mL} / \mathrm{min}$, with a linear gradient starting $5 \mathrm{~min}$ after injection up to $60 \%$ $(\mathrm{v} / \mathrm{v})$ acetonitrile, in the presence of $0.1 \%$ TFA. The chromatographic separation was carried out by a Waters ${ }^{\mathrm{TM}} 626$ system and equipped with a Waters ${ }^{\mathrm{TM}} 2487$ dual wavelength detector (Waters, Milan, Italy). Data at $220 \mathrm{~nm}$ and at $280 \mathrm{~nm}$ were recorded and elaborated by using the software Empower Pro (Waters, Milan, Italy). Results are expressed as total peak area measured at $220 \mathrm{~nm}$ that include the peptides that do not contain aromatic residuals that were quantified measuring the absorbance at $280 \mathrm{~nm}$ of the supernatant after TFA treatment. 


\section{Human Clinical Study}

This multicenter study was conducted at Texas Christian University (TCU), Fort Worth, TX, USA, and the University of Mary Hardin-Baylor (UMHB), Belton, TX, USA, in accordance with the Declaration of Helsinki guidelines and registered with the ISRCTN registry (ISRCTN38903788). All the procedures were approved by the Institutional Review Board of Texas Christian University (IRB approval: 1707-080-1707) and University of Mary Hardin-Baylor (IRB approval: 44). Despite this being a multicenter trial, all blood analyses were sent to Heartland Assays, Iowa State University Research Park, Ames, IA, USA, to eliminate the risk of a study site effect.

\section{Participants}

Fifteen healthy men (TCU $=10 ; \mathrm{UMHB}=5 ; n=15)$ between the ages of 18-35 years were recruited to participate in this study (Table 1). In order to qualify for this study, participants needed to have normal body weight (body mass index (BMI) of $19-24.99 \mathrm{~kg} / \mathrm{m}^{2}$ ) and be recreationally active (according to the American College of Sports Medicine Guidelines). Subjects were not allowed to consume any nutritional or ergogenic supplement known to affect measures of the current study for the prior 6 weeks, including probiotics, prebiotics, and digestive enzymes. Exclusion criteria included any individual who was treated for or diagnosed with a gastrointestinal, cardiac, respiratory, circulatory, musculoskeletal, metabolic, immune, autoimmune, psychiatric, hematological, neurological, or endocrinological disorder. Participants who were determined to not be weight stable defined as measured body mass deviating by $2 \%$ or more, and participants who were not willing to abstain from alcohol, nicotine, and caffeine for $12 \mathrm{~h}$ prior to each visit were excluded. Participants who met the necessary inclusion criteria were further encouraged not to change their current physical activity levels and to refrain from exercise for $24 \mathrm{~h}$ before starting the clinical trial. At TCU, participants were randomized via the RAND function in Microsoft Excel. Of the 10 participants completed at TCU, 3 completed the treatment first, while the other 7 completed the placebo. At UMHB, participants were randomized using Random.org. Of the 5 participants completed at UMHB, all completed the treatment first and placebo second.

Table 1 Subject characteristics at baseline $(n=15)$

\begin{tabular}{ll}
\hline Age (years) & $24.2 \pm 5.0$ \\
Height $(\mathrm{cm})$ & $178.0 \pm 7.6$ \\
Weight $(\mathrm{kg})$ & $85.3 \pm 12.9$ \\
Body Fat $(\%)$ & $16.7 \pm 5.8$
\end{tabular}

Data is presented as means \pm standard deviation

\section{Experimental Protocol}

A randomized, double-blind, crossover pilot study was performed to assess the amino acid concentration in the blood after the administration of a plant protein with or without coadministration of a probiotic supplement. Prior to beginning the study, all participants signed an IRB-approved informed consent document and completed a health history questionnaire to determine study eligibility. Two supplementation periods that each spanned 2 weeks were completed and separated by a washout period of 4 weeks. For each study visit, all participants reported to the laboratory between 06:00 and 10:00 $\mathrm{h}$ after observing an 8-10-h fast. Daily diet was recorded, and subjects were asked to repeat the same diet for 2 weeks leading up to the second experimental testing. Participants were randomly assigned to ingest either a single daily $20-\mathrm{g}$ dose of a pea protein plus placebo or a single daily 20 -g dose of a pea protein plus probiotic. Upon arrival for each study visit, participants had their resting heart rate, blood pressure, body mass, height, and body fat measured using skinfold. The occurrence of adverse events was recorded throughout completion of the supplementation and study visits. Adverse events were collected through spontaneous reporting by the study participants, clinical evaluation, or interaction of a research team member with a study participant. Subjects rested semi-supine for placement of a Teflon catheter into an antecubital vein for multiple blood sampling. The catheter was kept patent by flushing with $3 \mathrm{ml}$ of $0.9 \%$ sodium chloride. Following baseline sampling, participants ingested their respective supplement. Thereafter, blood samples were taken at 30-, 60-, 120-, and 180-min post-ingestion (Table 2). Subsequently, a 4-week washout period was implemented, followed by the opposite condition. Whole blood was collected and transferred into Becton Dickinson (BD) $8.5 \mathrm{ml}$ tubes (BD Vacutainer SST) for obtaining serum and BD $10.0 \mathrm{ml}$ (Vacutainer Sodium Heparin) tubes for obtaining plasma and subsequently centrifuged at $1500 \times g$ for $15 \mathrm{~min}$ at $4{ }^{\circ} \mathrm{C}$. Resulting serum and plasma were then aliquoted and stored at $-80{ }^{\circ} \mathrm{C}$ until subsequent analyses.

\section{Supplementation}

Participants co-administered $20 \mathrm{~g}$ of protein (vegetable protein isolated from yellow pea (Pisum sativum), NUTRALYS $®$ S85F, Roquette Freres S.A., France) with either 10 billion CFU of a multi-strain probiotic (5 billion CFU L. paracasei LP-DG ${ }^{\circledR}$ (CNCM I-1572) and 5 billion CFU L. paracasei LPC-S01 (DSM 26760), AminoAlta ${ }^{\mathrm{TM}}$, SOFAR S.p.A., Italy) or a placebo (maltodextrin, Glucidex ${ }^{\circledR} 12$, Roquette Freres S.A., France), in a randomized order. The study materials were provided in a dual chamber sachet, separating the protein from the probiotic or placebo until the time of consumption. Subjects were instructed to open the pouch, mix the 
Table 2 Study design

\begin{tabular}{|c|c|c|c|c|c|c|}
\hline $\begin{array}{l}\text { Screening and } \\
\text { consent }\end{array}$ & Baseline testing & Day 1-14 & Day 15 & $\begin{array}{l}\text { Day } 16- \\
43\end{array}$ & Day $44-57$ & Day 58 \\
\hline Screening & $\begin{array}{l}\text { Body height and } \\
\text { weight }\end{array}$ & \multirow{7}{*}{$\begin{array}{l}2 \text { weeks of } \\
\text { supplementation }+ \\
\text { dietary recording }\end{array}$} & Body height and weight & \multirow{8}{*}{$\begin{array}{l}4 \text { weeks } \\
\text { of } \\
\text { wash- } \\
\text { out }\end{array}$} & \multirow{7}{*}{$\begin{array}{l}2 \text { weeks of } \\
\text { supplementation }+ \\
\text { dietary recording }\end{array}$} & Body height and weight \\
\hline $\begin{array}{l}\text { Informed } \\
\text { consent }\end{array}$ & Vitals & & $\begin{array}{l}\text { Supplementation } \\
\text { adherence check }\end{array}$ & & & $\begin{array}{l}\text { Supplementation } \\
\text { adherence check }\end{array}$ \\
\hline Demographics & $\begin{array}{l}\text { Instructions for } \\
\text { supplementa- } \\
\text { tion }\end{array}$ & & Dietary recording check & & & Dietary recording check \\
\hline Health history & $\begin{array}{l}\text { Instructions for } \\
\text { dietary } \\
\text { recording }\end{array}$ & & Adverse event check & & & Adverse event check \\
\hline $\begin{array}{l}\text { Exercise } \\
\text { history }\end{array}$ & $\begin{array}{l}\text { Dietary } \\
\quad \text { restrictions }\end{array}$ & & Fasting blood draw & & & Fasting blood draw \\
\hline $\begin{array}{l}\text { Body height } \\
\text { and weight }\end{array}$ & & & $\begin{array}{l}\text { Ingestion of plant protein } \\
\text { with or without a } \\
\text { probiotic }\end{array}$ & & & $\begin{array}{l}\text { Ingestion of plant protein } \\
\text { with or without a } \\
\text { probiotic }\end{array}$ \\
\hline Vitals & & & $\begin{array}{l}\text { Subsequent blood draws } \\
\quad(30,60,120,180 \mathrm{~min})\end{array}$ & & & $\begin{array}{l}\text { Subsequent blood draws } \\
\quad(30,60,120,180 \mathrm{~min})\end{array}$ \\
\hline Randomization & & & & & & \\
\hline
\end{tabular}

ingredients with $473 \mathrm{ml}$ of their favorite non-protein containing beverage, and consume the product immediately. On weekdays, subjects reported to the lab daily and consumed the study materials in front of the researchers to ensure compliance. On Fridays, subjects received two additional sachets to be taken during the weekend. Study material identity and potency was verified by an independent lab (for probiotic, Covance Laboratories Inc., Madison, WI, USA; for protein content and amino acid composition, Table 3, Eurofins,

Table 3 Amino acid profile of the study material (Eurofins Certificate of Analysis, 2,696,852-0, November 20, 2019)

\begin{tabular}{ll}
\hline Amino acid & {$[\mathrm{mg} / \mathrm{g}$ of protein $]$} \\
\hline Alanine & 43 \\
Arginine & 88 \\
Aspartic acid & 117 \\
Cysteine & 9 \\
Glutamic acid & 167 \\
Glycine & 41 \\
Histidine & 25 \\
Isoleucine & 48 \\
Leucine & 83 \\
Lysine & 74 \\
Methionine & 12 \\
Phenylalanine & 54 \\
Proline & 45 \\
Serine & 50 \\
Threonine & 40 \\
Tryptophan & 10 \\
Tyrosine & 39 \\
Valine & 51 \\
\hline
\end{tabular}

Madison, WI, USA) after the completion of the study and blinded analysis of the results.

\section{Amino Acid Analysis}

EZ:faast ${ }^{\circledR}$ amino acid analysis kits (Phenomenex, Torrance, CA) were used for liquid chromatographic analysis of amino acids using tandem-mass spectrometry (LC/MS/MS) and electrospray ionization (ESI). The procedure consisted of solid phase extraction of $25 \mu$ of plasma with internal standards by a sorbent tip attached to a syringe with an eluting solvent (a 3:2 mixture of sodium hydroxide with $77 \%$ n-propanol and $23 \%$ 3-picoline). The free amino acids were then derivatized by adding a mixture of $17.4 \%$ propyl chloroformate, $11 \%$ isooctane, and $71.6 \%$ chloroform. The resulting mixture was vortexed and allowed to sit at room temperature for $1 \mathrm{~min}$, followed by liquid-liquid extraction with isooctane. Fifty microliters of the organic layer were removed, dried under nitrogen gas, and suspended in the HPLC run solvents before being injected into the LC/MS/MS. Chromatographic separation of the derivatized amino acids was conducted on an EZ:faast amino acid analysis-mass spectrometry column $(250 \times$ $2.0 \mathrm{~mm}$ i.d., $4 \mu \mathrm{m}$ ) using an Agilent 6460 triple quadrupole LC/MS/MS system (Santa Clara, CA). Ten millimeters of ammonium formate in water with $0.2 \%$ formic acid (mobile phase A) and $10 \mathrm{mM}$ ammonium formate in methanol with $0.2 \%$ formic acid (mobile phase B) were used as solvent system with gradient conditions of $68 \% \mathrm{~B}$ at 0 min to $83 \% \mathrm{~B}$ over $13 \mathrm{~min}$ with a flow rate of $0.25 \mathrm{ml} / \mathrm{min}$. Amino acids and internal standard data were collected using the dynamic multiple reaction monitoring mode using MassHunter acquisition software (Agilent, Santa Clara, CA). MassHunter 
Quantitation software was used to quantitate the unknown plasma samples based on best fit standard curves.

\section{Statistical Analysis}

The area under the concentration vs. time curve (AUC) was calculated for each of the 22 amino acids, as well as BCAAs, EAAs, and total amino acids, via the linear trapezoidal rule and using all available time points. Cmax was defined as the maximum observed concentration, and Tmax was the time at which Cmax was reached. AUC values were compared between conditions via paired sample $t$ tests. A $p$ value $<0.05$ was considered statistically significant. Analyses were performed in R (v. 3.6.1) using the PKNCA package. Cohen's $\mathrm{d}$ effect sizes were calculated as the mean difference between conditions (i.e., protein plus probiotic minus protein) divided by the pooled standard deviation. Percent differences between treatments were calculated as the mean difference between conditions minus the value in the Protein condition times one hundred. Results are expressed as mean \pm standard deviation (SD) unless otherwise noted. In vitro digestion data are the results of three independent determinations, each performed in triplicate. Analysis of variance of the in vitro digestion data was performed adopting the least significant difference (LSD). Data were analyzed using Statgraphics XV, version 15.1.02 (StatPoint, Warrenton, VA, USA).

\section{Results}

\section{In Vitro Tests}

SDS-PAGE analysis of the 8 different conditions showed that the combination of pepsin and pancreatin, with or without the individual or combined strains, no longer contained intact proteins (Table 4). In contrast, the individual strain alone or in combination did not show evident proteolytic activity. Analysis by RP-HPLC showed that the addition of the probiotic strains resulted in different peptides compared with digestive enzymes alone. L. paracasei LP-DG® showed a greater increase with rice protein in comparison with $L$. paracasei LPC-S01, whereas the combination of two strains showed a synergistic effect with pea protein. Based on the outcome of the in vitro tests, the combination of $L$. paracasei LP-DG® and $L$. paracasei LPC-S01 with pea protein was chosen for the human clinical study, to investigate if the probiotic strains can increase amino acid appearance in the blood, when coadministered with plant proteins.

\section{Human Data}

L. paracasei LP-DG® (5 billion CFU per day), L. paracasei LPC-S01 (5 billion CFU per day), and pea protein supplementation ( $20 \mathrm{~g}$ per day) were safe in healthy adults. No adverse events were observed during the duration of the clinical study in either group.

Probiotic administration significantly increased area under the curve (AUC) (Table 5) for methionine $(+20.0 \%)$, histidine $(+40.4 \%)$, valine $(+21.5 \%)$, leucine $(+23.3 \%)$, isoleucine $(+$ $26.0 \%)$, tyrosine $(+16.0 \%)$, total BCAA $(+22.8 \%)$, and total EAA $(+16.0 \%)$ concentrations.

Probiotic administration significantly increased methionine $(+16.3 \%)$, histidine $(+49.2 \%)$, valine $(+24.7 \%)$, leucine $(+$ $25.2 \%)$, isoleucine $(+26.1 \%)$, tyrosine $(+11.6 \%)$, total BCAA $(+26.8 \%)$, and total EAA $(+15.6 \%)$ maximum concentrations (Table 6).

Probiotic administration did not alter the time to reach the maximum concentration (Table 7).

\section{Discussion}

Growing transition to more plant-based, whole-food, sustainable diets raised questions about the protein adequacy of vegetarian and vegan diets. In addition, a reduction of animal protein intake, in particular meat consumption, has recently become more prevalent in Western countries. Protein intake is usually the highest in meat-eaters, followed by fish-eaters, lacto-ovo vegetarians, and vegans [16]. Insufficient protein intake from vegetarian diets may occur if the diets are low in protein-rich foods such as legumes, nuts, or seeds; however, there is currently no evidence that a balanced vegetarian diet provides inadequate total protein intakes [16]. Plant proteins differ in digestibility and amino acid composition from animal proteins. Specifically, plant proteins such as pea or rice are lower in leucine and total BCAA content, amino acids that have been linked to muscle health by activating MPS [17]. In contrast to omnivores, people following a vegetarian diet have lower circulating serum BCAA concentrations, which have been linked to lower dietary intake of BCAAs and also to changes in the gut microbiota composition resulting in upregulation of the gut microbial pathway for the degradation of BCAAs [18].

Probiotics function predominately in the large intestine. There is currently no evidence that amino acids liberated from bacterial fermentation in the large intestine alter plasma amino acid concentrations of the host; however, certain probiotic strains have proteolytic properties and have been linked to an increased production of digestive enzymes and subsequently improved host protein utilization [12]. Thus, the purpose of this study was to investigate the individual and potential additive or synergistic effects of $L$. paracasei LP-DG® and/or L. paracasei LPC-S01 on the in vitro digestion of different plant protein sources, in conjunction with a human study investigating post-prandial changes in blood amino acids in response to a $20 \mathrm{~g}$ protein bolus, with or without the probiotic. 
Table 4 Analysis of overall proteolysis by RP-HPLC separation

\begin{tabular}{llllll}
\hline Treatment & \multicolumn{2}{l}{ Rice } & & \multicolumn{2}{l}{ Pea } \\
\cline { 2 - 3 } & Area $\left(* 10^{6}\right)$ & $\Delta, \%$ & & Area $\left(* 10^{6}\right)$ & $\Delta, \%$ \\
\hline Absorbance at $220 \mathrm{~nm}$ & & & & & \\
Pepsin + pancreatin & & & & \\
Pepsin + pancreatin + L. paracasei LP-DG & $80.2 \pm 0.15^{*}$ & +2.6 & & $107 \pm 0.60$ & \\
Pepsin + pancreatin + L. paracasei LPC-S01 & $78.4 \pm 0.21$ & +0.3 & & $111 \pm 0.80^{*}$ & +3.7 \\
Pepsin + pancreatin + LP-DG + LPC-S01 & $80.6 \pm 0.18^{*}$ & +3.1 & & $114 \pm 0.70^{* *}$ & +6.5 \\
Absorbance at 280 nm & & & & & \\
Pepsin + pancreatin & $5.1 \pm 0.10$ & & & $11.9 \pm 0.06$ & \\
Pepsin + pancreatin + L. paracasei LP-DG & $5.4 \pm 0.09^{*}$ & +5.9 & & $12.0 \pm 0.08$ & +0.8 \\
Pepsin + pancreatin + L. paracasei LPC-S01 & $5.2 \pm 0.08$ & +2.0 & & $12.2 \pm 0.02^{*}$ & +2.5 \\
Pepsin + pancreatin + LP-DG + LPC-S01 & $5.4 \pm 0.10^{*}$ & +5.9 & & $12.6 \pm 0.07^{* *}$ & +5.6 \\
\hline
\end{tabular}

Data is presented as means \pm standard deviation

*Significantly different from control $(p<0.05)$

$* *$ Significantly different from control and single strain $(p<0.05)$

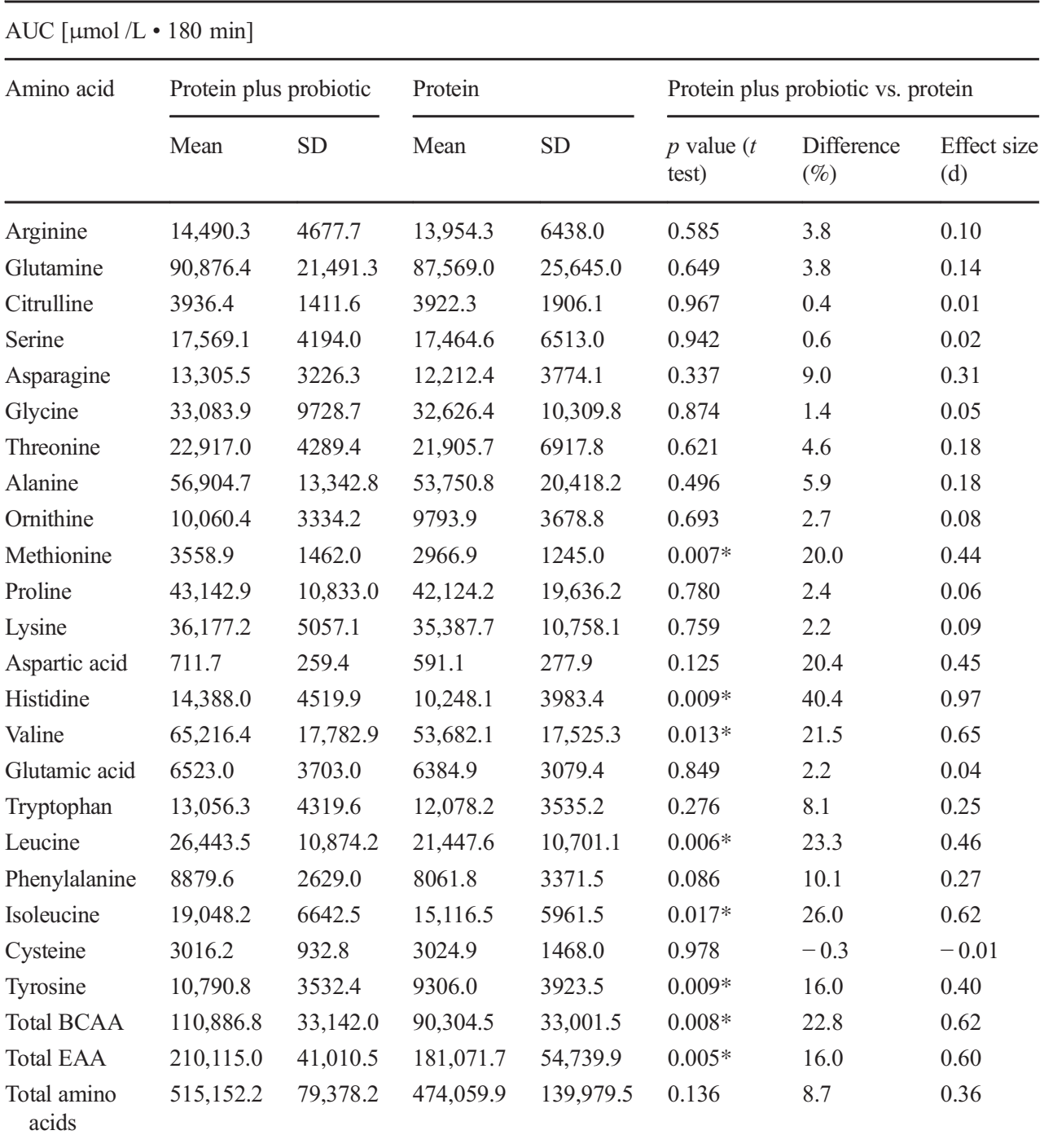

Table 5 Individual amino acids, total BCAA, total EAA and total amino acid area under the curve (AUC) 
Table 6 Individual amino acids, total BCAA, total EAA, and total amino acid maximum concentration (Cmax)

\begin{tabular}{|c|c|c|c|c|c|c|c|}
\hline \multicolumn{8}{|l|}{$\mathrm{Cmax}[\mu \mathrm{mol} / \mathrm{L}]$} \\
\hline \multirow[t]{2}{*}{ Amino acid } & \multicolumn{2}{|c|}{$\begin{array}{l}\text { Protein plus } \\
\text { probiotic }\end{array}$} & \multicolumn{2}{|l|}{ Protein } & \multicolumn{3}{|c|}{ Protein plus probiotic vs. protein } \\
\hline & Mean & SD & Mean & SD & $p$ value ( $t$ test) & Difference $(\%)$ & Effect size $(d)$ \\
\hline Arginine & 102.4 & 30.9 & 106.6 & 42.9 & 0.556 & -3.9 & -0.11 \\
\hline Glutamine & 601.7 & 131.8 & 599.9 & 131.2 & 0.974 & 0.3 & 0.01 \\
\hline Citrulline & 26.4 & 9.7 & 27.4 & 10.5 & 0.580 & -3.6 & -0.10 \\
\hline Serine & 128.3 & 28.4 & 130.4 & 47.5 & 0.860 & -1.6 & -0.05 \\
\hline Asparagine & 101.3 & 22.6 & 96.1 & 31.0 & 0.602 & 5.5 & 0.19 \\
\hline Glycine & 228.3 & 56.7 & 237.3 & 66.5 & 0.625 & -3.8 & -0.15 \\
\hline Threonine & 161.9 & 30.5 & 159.2 & 51.0 & 0.861 & 1.7 & 0.06 \\
\hline Alanine & 414.6 & 148.2 & 389.6 & 135.3 & 0.418 & 6.4 & 0.18 \\
\hline Ornithine & 72.8 & 23.4 & 72.0 & 23.7 & 0.881 & 1.2 & 0.04 \\
\hline Methionine & 23.2 & 8.9 & 19.9 & 6.3 & $0.008 *$ & 16.3 & 0.42 \\
\hline Proline & 318.7 & 129.1 & 323.0 & 176.2 & 0.905 & -1.3 & -0.03 \\
\hline Lysine & 276.0 & 45.9 & 266.0 & 70.5 & 0.627 & 3.7 & 0.17 \\
\hline Aspartic acid & 7.3 & 3.6 & 5.9 & 3.6 & 0.208 & 22.7 & 0.37 \\
\hline Histidine & 110.0 & 59.1 & 73.7 & 24.5 & $0.048 *$ & 49.2 & 0.80 \\
\hline Valine & 490.5 & 174.5 & 393.4 & 94.2 & $0.034 *$ & 24.7 & 0.69 \\
\hline Glutamic acid & 50.4 & 24.3 & 51.9 & 22.5 & 0.740 & -3.0 & -0.07 \\
\hline Tryptophan & 90.8 & 24.7 & 88.7 & 19.7 & 0.796 & 2.4 & 0.10 \\
\hline Leucine & 200.7 & 80.3 & 160.3 & 71.6 & $0.043 *$ & 25.2 & 0.53 \\
\hline Phenylalanine & 57.6 & 16.8 & 54.8 & 18.9 & 0.252 & 5.2 & 0.16 \\
\hline Isoleucine & 149.4 & 46.8 & 118.4 & 41.6 & $0.020 *$ & 26.1 & 0.70 \\
\hline Cysteine & 19.5 & 5.3 & 19.8 & 7.5 & 0.832 & -1.8 & -0.06 \\
\hline Tyrosine & 70.6 & 23.2 & 63.3 & 22.6 & $0.014 *$ & 11.6 & 0.32 \\
\hline Total BCAA & 833.8 & 237.5 & 657.8 & 192.6 & $0.009^{*}$ & 26.8 & 0.81 \\
\hline Total EAA & 1512.6 & 315.7 & 1308.2 & 301.3 & $0.022 *$ & 15.6 & 0.66 \\
\hline Total amino acids & 3566.6 & 586.2 & 3389.4 & 818.6 & 0.371 & 5.2 & 0.25 \\
\hline
\end{tabular}

The primary findings of the in vitro data showed increased proteolysis and a synergistic effect with the combination of L. paracasei LP-DG® and L. paracasei LPC-S01 (+6.5\% at $220 \mathrm{~nm} ;+5.6 \%$ at $280 \mathrm{~nm}$ ) compared with either strain alone for pea protein. Similar to the in vitro data, results from the human clinical trial showed increases in AUC for total BCAA $(+22.8 \%)$ and total EAA $(+16.0 \%)$ concentrations after 2 weeks of probiotic supplementation. Moreover, increases in leucine $(+23.3 \%)$, isoleucine $(+26.0 \%)$, valine $(+21.5 \%)$, and total EAA $(+16.0 \%)$ absorption suggest a potential for administering $L$. paracasei LP-DG® and L. paracasei LPCS01 for optimization of amino acid absorption following pea protein consumption. Taken together, these data illustrate that this could be a strategy to enhance absorption levels of plantbased proteins and have implications on increasing protein utilization following the post-absorptive period in the human gut.

For building muscle mass and for maintaining muscle mass through a positive muscle protein balance, an overall daily protein intake in the range of $1.4-2.0 \mathrm{~g}$ protein $/ \mathrm{kg}$ body weight/day $(\mathrm{g} / \mathrm{kg} / \mathrm{d})$ is sufficient for most exercising individuals, and acute protein doses should strive to contain 1700 to $3000 \mathrm{mg}$ of leucine, in addition to a balanced array of 10-12 g of EAAs [14]. EAAs play a critical role for achieving maximal rates of MPS making protein sources that are rich in EAAs the preferred sources of protein [14]. Amino acid analysis of the study material confirmed the relatively low leucine content (approx. 8\%) of pea protein, in comparison with animal proteins such as whey protein, containing approx. $10-11 \%$ of leucine [19]. When compensating for the low leucine content by using large isonitrogenous doses (48-50 g of protein), rice [19] and pea protein [20] have been shown to be as effective as whey protein in increasing lean body mass and strength when combined with resistance exercise; however, the ability of standard protein doses (18-24 g of protein) has not been studied yet. Increasing leucine AUC concentration by $23 \%$ and total EAA concentrations by $16 \%$ by co-ingestion of probiotics helps to overcome the compositional shortcomings 
Table 7 Individual amino acids, total BCAA, total EAA, and total amino acid time to maximum concentration (Tmax)

\begin{tabular}{|c|c|c|c|c|c|c|c|}
\hline \multicolumn{8}{|l|}{$\operatorname{Tmax}[\min ]$} \\
\hline \multirow[t]{2}{*}{ Amino acid } & \multicolumn{2}{|c|}{$\begin{array}{l}\text { Protein plus } \\
\text { probiotic }\end{array}$} & \multicolumn{2}{|c|}{ Protein } & \multicolumn{3}{|c|}{ Protein plus probiotic vs. protein } \\
\hline & Mean & SD & Mean & SD & $p$ value ( $t$ test) & Difference $(\%)$ & Effect size $(d)$ \\
\hline Arginine & 58.0 & 41.6 & 40.0 & 14.6 & 0.057 & 45.0 & 0.58 \\
\hline Glutamine & 54.0 & 41.2 & 60.0 & 56.7 & 0.748 & -10.0 & -0.12 \\
\hline Citrulline & 56.0 & 46.6 & 48.0 & 49.2 & 0.546 & 16.7 & 0.17 \\
\hline Serine & 52.0 & 40.0 & 40.0 & 29.3 & 0.271 & 30.0 & 0.34 \\
\hline Asparagine & 58.0 & 43.1 & 46.0 & 33.8 & 0.395 & 26.1 & 0.31 \\
\hline Glycine & 70.0 & 55.2 & 52.0 & 56.1 & 0.398 & 34.6 & 0.32 \\
\hline Threonine & 62.0 & 51.3 & 50.0 & 40.4 & 0.458 & 24.0 & 0.26 \\
\hline Alanine & 78.0 & 54.1 & 56.0 & 49.3 & 0.294 & 39.3 & 0.43 \\
\hline Ornithine & 72.0 & 45.1 & 52.0 & 33.0 & 0.096 & 38.5 & 0.51 \\
\hline Methionine & 48.0 & 42.1 & 38.0 & 13.7 & 0.388 & 26.3 & 0.32 \\
\hline Proline & 66.0 & 53.4 & 56.0 & 54.2 & 0.632 & 17.9 & 0.19 \\
\hline Lysine & 50.0 & 40.4 & 54.0 & 44.2 & 0.784 & -7.4 & -0.09 \\
\hline Aspartic acid & 46.0 & 35.6 & 50.0 & 43.4 & 0.774 & -8.0 & -0.10 \\
\hline Histidine & 62.0 & 51.3 & 44.0 & 43.7 & 0.246 & 40.9 & 0.38 \\
\hline Valine & 60.0 & 40.9 & 58.0 & 53.7 & 0.914 & 3.4 & 0.04 \\
\hline Glutamic acid & 42.0 & 37.3 & 74.0 & 69.8 & 0.088 & -43.2 & -0.57 \\
\hline Tryptophan & 52.0 & 43.1 & 72.0 & 54.1 & 0.191 & -27.8 & -0.41 \\
\hline Leucine & 60.0 & 40.9 & 44.0 & 15.5 & 0.120 & 36.4 & 0.52 \\
\hline Phenylalanine & 52.0 & 24.0 & 42.0 & 15.2 & 0.096 & 23.8 & 0.50 \\
\hline Isoleucine & 52.0 & 38.4 & 44.0 & 15.5 & 0.413 & 18.2 & 0.27 \\
\hline Cysteine & 54.0 & 45.6 & 72.0 & 58.7 & 0.447 & -25.0 & -0.34 \\
\hline Tyrosine & 58.0 & 36.7 & 46.0 & 15.5 & 0.233 & 26.1 & 0.43 \\
\hline Total BCAA & 66.0 & 42.7 & 54.0 & 39.6 & 0.458 & 22.2 & 0.29 \\
\hline Total EAA & 60.0 & 40.9 & 54.0 & 39.6 & 0.689 & 11.1 & 0.15 \\
\hline Total amino acids & 58.0 & 43.1 & 60.0 & 52.0 & 0.910 & -3.3 & -0.04 \\
\hline
\end{tabular}

of plant proteins and could help to elevate BCAA levels in the blood to comparable levels of animal proteins, thereby potentially removing the need to increase the dose of plant proteins to achieve similar benefits of protein supplementation on muscle health. In addition to increasing the effects of resistance training on MPS, protein rich diets are used for weight management and weight loss during calorie-restricted diets. The total amount of muscle mass is the sum of MPS and muscle protein breakdown (MPB). A net positive muscle protein balance can be achieved if MPS is greater than MPB [21]. During energy restriction, MPB increases, resulting in a loss of fatfree mass, particularly if rates of weight loss exceed $1.0 \%$ body mass loss per week [22]. Higher protein intakes (2.3$3.1 \mathrm{~g} / \mathrm{kg} / \mathrm{d}$ ) may be needed to maximize the retention of lean body weight [14] and promotion of fat loss [23] in resistance trained subjects during hypocaloric periods. Plant proteins with the addition of probiotics might be more effective in maintaining muscle mass during calorie-restricted diets, due to the greater increase in hyperaminoacidemia, especially in plasma leucine levels that stimulate MPS [21].

Athletes have varying gut microbiota compositions that appear to reflect the activity level of the host in comparison with sedentary people, with the differences linked primarily to the volume of exercise and amount of protein consumption [24]. The probiotic strains used in this study have been shown to increase absorption of key nutrients of specific importance to athletes, such as amino acids from protein. In addition, probiotics offer various health benefits for active people [25], such as improving the integrity of the gut-barrier function [26], and the administration of selected anti-inflammatory probiotic strains has been linked to improved recovery from muscle-damaging exercise [27]. Immune health in athletes is compromised with excessive training load, psychological stress, disturbed sleep, and environmental extremes, all of which can contribute to an increased risk of respiratory tract infections [28]. Approximately $70 \%$ of the immune system is 
located in the gut, and probiotic supplementation has been shown to promote a healthy immune response [25]. Studies in athletes have shown to improve immune health by reducing the number of episodes, severity, and duration of upper respiratory tract infections following intense, prolonged exercise [29].

Pea and rice protein are both incomplete proteins [19]. While rice protein is low in lysine, pea protein is low in methionine and cysteine. Most commercial plant protein products combine pea and rice protein to create a plant protein blend matching the requirements of a complete protein, as rice protein has higher contents of methionine and cysteine, and pea protein is rich in lysine. The co-administration of probiotics with pea protein increased methionine AUC levels by $20 \%$ in our study, offering an alternative nutritional approach to overcome the low methionine content in pea protein. The increase in appearance in the blood of sulfur-containing amino acids might have an additional health benefit. While carbohydrate fermentation is linked to beneficial health effects on the host due to the generation of short-chain fatty acids, protein fermentation, which mainly occurs in the distal colon, has been linked to the production of metabolites such as sulfides, amines, or ammonia [30]. Thus, increased absorption of sulfur-containing amino acids by the host might reduce the formation of sulfides.

Limitation of our study was the lack of urine and fecal analysis to confirm improved protein retention. Plasma concentration of amino acids does not directly relate to muscle protein synthesis or breakdown, which would need to be determined by muscle biopsies. The in vitro analysis of "protein hydrolysis" under small intestinal conditions is not reflective of the in vivo response as probiotics function predominately in the large intestine. Future studies should investigate the effects on animal proteins.

\section{Conclusion}

In conclusion, results from the present study indicate that coadministration of plant protein with a multi-strain probiotic can increase post-prandial changes in blood amino acids including EAAs and BCAAs, which are closely linked to optimization of muscle health. Probiotic supplementation can be an important nutritional strategy to overcome compositional shortcomings of plant proteins.

Acknowledgments The sponsor played no role in collecting the data, analyzing the data, interpreting the results, or preparing the manuscript.

Authors' Contributions S.I. and M.M. designed and performed the in vitro tests. R.J., M.P., W.F., A.B., and J.M.O. designed the human study. A.J.A., J.M.O., J.Z., S.U., and L.T. collected the data. G.M.T. performed the statistical analyses of the human study, and M.M. performed the statistical analyses of the in vitro analysis. R.J. wrote the manuscript. All authors viewed and approved the final version of the manuscript.

Funding Information This study was supported by Sofar S.p.A., Italy.

\section{Compliance with Ethical Standards}

Conflict of Interest W.F. and A.B. are employees of the manufacturer of the probiotic strain, Sofar S.p.A. however were only involved in the design of the study. A.B. is inventor of patent WO2017/195182. All other authors declare no conflict of interest.

Open Access This article is licensed under a Creative Commons Attribution 4.0 International License, which permits use, sharing, adaptation, distribution and reproduction in any medium or format, as long as you give appropriate credit to the original author(s) and the source, provide a link to the Creative Commons licence, and indicate if changes were made. The images or other third party material in this article are included in the article's Creative Commons licence, unless indicated otherwise in a credit line to the material. If material is not included in the article's Creative Commons licence and your intended use is not permitted by statutory regulation or exceeds the permitted use, you will need to obtain permission directly from the copyright holder. To view a copy of this licence, visit http://creativecommons.org/licenses/by/4.0/.

\section{References}

1. Cai H, Rodriguez BT, Zhang W, Broadbent JR, Steele JL (2007) Genotypic and phenotypic characterization of Lactobacillus casei strains isolated from different ecological niches suggests frequent recombination and niche specificity. Microbiology 153(8):2656 2665. https://doi.org/10.1099/mic.0.2007/006452-0

2. Radicioni M, Koirala R, Fiore W, Leuratti C, Guglielmetti S, Arioli S (2019) Survival of $L$. casei $D^{\circledR}$ (Lactobacillus paracasei CNCMI1572) in the gastrointestinal tract of a healthy paediatric population. Eur J Nutr 58(8):3161-3170. https://doi.org/10.1007/ s00394-018-1860-5

3. Arioli S, Koirala R, Taverniti V, Fiore W, Guglielmetti S (2018) Quantitative recovery of viable Lactobacillus paracasei CNCM I1572 (L. casei DG®) after gastrointestinal passage in healthy adults. Front Microbiol 9:1720. https://doi.org/10.3389/fmicb. 2018.01720

4. Ferrario C, Taverniti V, Milani C, Fiore W, Laureati M, De Noni I, Stuknyte M, Chouaia B, Riso P, Guglielmetti S (2014) Modulation of fecal Clostridiales Bacteria and butyrate by probiotic intervention with Lactobacillus paracasei DG varies among healthy adults. J Nutr 144(11):1787-1796. https://doi.org/10.3945/jn.114.197723

5. Cremon C, Guglielmetti S, Gargari G, Taverniti V, Castellazzi AM, Valsecchi C, Tagliacarne C, Fiore W, Bellini M, Bertani L, Gambaccini D, Cicala M, Germanà B, Vecchi M, Pagano I, Barbaro MR, Bellacosa L, Stanghellini V, Barbara G (2018) Effect of Lactobacillus paracasei CNCM I-1572 on symptoms, gut microbiota, short chain fatty acids, and immune activation in patients with irritable bowel syndrome: a pilot randomized clinical trial. United European Gastroenterol J 6(4):604-613. https://doi. org/10.1177/2050640617736478

6. Compare D, Rocco A, Coccoli P, Angrisani D, Sgamato C, Iovine B, Salvatore U, Nardone G (2017) Lactobacillus casei DG and its postbiotic reduce the inflammatory mucosal response: an ex-vivo organ culture model of postinfectious irritable bowel syndrome. 
BMC Gastroenterol 17(1):53. https://doi.org/10.1186/s12876-0170605-x

7. Tursi A, Brandimarte G, Giorgetti GM, Elisei W (2006) Mesalazine and/or Lactobacillus casei in preventing recurrence of symptomatic uncomplicated diverticular disease of the colon: a prospective, randomized, open-label study. J Clin Gastroenterol 40(4):312-316. https://doi.org/10.1097/01.mcg.0000210092.77296.6d

8. Tursi A, Brandimarte G, Giorgetti GM, Elisei W (2008) Mesalazine and/or Lactobacillus casei in maintaining long-term remission of symptomatic uncomplicated diverticular disease of the colon. Hepatogastroenterology 55(84):916-920

9. Tursi A, Brandimarte G, Elisei W, Picchio M, Forti G, Pianese G, Rodino S, D'Amico T, Sacca N, Portincasa P, Capezzuto E, Lattanzio R, Spadaccini A, Fiorella S, Polimeni F, Polimeni N, Stoppino V, Stoppino G, Giorgetti GM, Aiello F, Danese S (2013) Randomised clinical trial: mesalazine and/or probiotics in maintaining remission of symptomatic uncomplicated diverticular disease a double-blind, randomised, placebo-controlled study. Aliment Pharmacol Ther 38(7):741-751. https://doi.org/10.1111/apt.12463

10. Turco F, Andreozzi P, Palumbo I, Zito FP, Cargiolli M, Fiore W, Gennarelli N, De Palma GD, Sarnelli G, Cuomo R (2017) Bacterial stimuli activate nitric oxide colonic mucosal production in diverticular disease. Protective effects of L. casei DG® (Lactobacillus paracasei CNCM I-1572). United European Gastroenterol J 5(5): 715-724. https://doi.org/10.1177/2050640616684398

11. Balzaretti S, Taverniti V, Rondini G, Marcolegio G, Minuzzo M, Remagni MC, Fiore W, Arioli S, Guglielmetti S (2015) The vaginal isolate Lactobacillus paracasei LPC-S01 (DSM 26760) is suitable for oral administration. Front Microbiol 6:952. https://doi.org/10. 3389/fmicb.2015.00952

12. Jäger R, Purpura M, Farmer S, Cash HA, Keller D (2018) Probiotic Bacillus coagulans GBI-30, 6086 improves protein absorption and utilization. Probiot Antimicrob Proteins 10(4):611-615. https://doi. org/10.1007/s12602-017-9354-y

13. Gorissen SHM, Crombag JJR, Senden JMG, Waterval WAH, Bierau J, Verdijk LB, van Loon LJC (2018) Protein content and amino acid composition of commercially available plant-based protein isolates. Amino Acids 50(12):1685-1695. https://doi.org/10. 1007/s00726-018-2640-5

14. Jäger R, Kerksick CM, Campbell BI, Cribb PJ, Wells SD, Skwiat TM, Purpura M, Ziegenfuss TN, Ferrando AA, Arent SM, SmithRyan AE, Stout JR, Arciero PJ, Ormsbee MJ, Taylor LW, Wilborn CD, Kalman DS, Kreider RB, Willoughby DS, Hoffman JR, Krzykowski JL, Antonio J (2017) International Society of Sports Nutrition Position Stand: protein and exercise. J Int Soc Sports Nutr 14:20. https://doi.org/10.1186/s12970-017-0177-8

15. Diether NE, Willing BP (2019) Microbial fermentation of dietary protein: an important factor in diet-microbe-host interaction. Microorganisms 7(1):19. https://doi.org/10.3390/ microorganisms 7010019

16. Mariotti F, Gardner CD (2019) Dietary protein and amino acids in vegetarian diets-a review. Nutrients 11:2661. https://doi.org/10. 3390/nu11112661

17. Norton LE, Layman DK (2006) Leucine regulates translation initiation of protein synthesis in skeletal muscle after exercise. J Nutr 136(2):533S-537S. https://doi.org/10.1093/jn/136.2.533S

18. Wang F, Wan Y, Yin K, Wei Y, Wang B, Yu X, Zheng J, Huang T, Song M, Li D (2019) Lower Circulating Branched-Chain Amino Acid Concentrations Among Vegetarians are Associated with Changes in Gut Microbial Composition and Function. Mol Nutr Food Res 63:e1900612. https://doi.org/10.1002/mnfr.201900612

19. Joy JM, Lowery RP, Wilson JM, Purpura M, De Souza EO, Wilson SMC, Kalman DS, Jäger R (2013) The effects of 8 weeks of whey or rice protein supplementation on body composition and exercise performance. Nutr J 12(1):86. https://doi.org/10.1186/1475-2891$12-86$

20. Babault N, Païzis C, Deley G, Guérin-Deremaux L, Saniez M-H, Lefranc-Millot C, Allaert FA (2015) Pea proteins oral supplementation promotes muscle thickness gains during resistance training: a double-blind, randomized, placebo-controlled clinical trial vs. whey protein. J Int Soc Sports Nutr 12:3. https://doi.org/10.1186/s12970014-0064-5

21. Phillips SM (2016) The impact of protein quality on the promotion of resistance exercise-induced changes in muscle mass. Nutr Metab (Lond) 13:64. https://doi.org/10.1186/s12986-016-0124-8

22. Garthe I, Raastad T, Refsnes PE, Koivisto, Sundgot-Borgen J (2011) Effect of two different weight-loss rates on body composition and strength and power-related performance in elite athletes. Int J Sport Nutr Exerc Metab:97-104. https://doi.org/10.1123/ ijsnem.21.2.97

23. Longland TM, Oikawa SY, Mitchell CJ, Devries MC, Phillips SM (2016) Higher compared with lower dietary protein during an energy deficit combined with intense exercise promotes greater lean mass gain and fat mass loss: a randomized trial. Am J Clin Nutr 103:738-746. https://doi.org/10.3945/ajcn.115.119339

24. Clarke SF, Murphy EF, O'Sullivan O, Lucey AJ, Humphreys M, Hogan A, Hayes P, O'Reilly M, Jeffery IB, Wood-Martin R, Kerins DM, Quigley E, Ross RP, O'Toole PW, Molloy MG, Falvey E, Shanahan F, Cotter PD (2014) Exercise and associated dietary extremes impact on gut microbial diversity. Gut 63:1913-1920. https://oi.org/10.1136/gutjnl-2013-306541

25. Jäger R, Mohr AE, Carpenter KC, Kerksick CM, Purpura M, Moussa A, Townsend JR, Lamprecht M, West NP, Black K, Gleeson M, Pyne DB, Wells SD, Arent SM, Smith-Ryan AE, Kreider RB, Campbell BI, Bannock L, Scheiman J, Wissent CJ, Pane M, Kalman DS, Pugh JN, ter Haar JA, Antonio J (2019) International society of sports nutrition position stand: probiotics. J Int Soc Sports Nutr 16:62. https://doi.org/10.1186/s12970-0190329-0

26. Lamprecht M, Bogner S, Schippinger G, Steinbauer K, Fankhauser F, Hallstroem S, Schuetz B, Greilberger JF (2012) Probiotic supplementation affects markers of intestinal barrier, oxidation, and inflammation in trained men; a randomized, double-blinded, placebo-controlled trial. J Int Soc Sports Nutr 9:45. https://doi.org/ 10.1186/1550-2783-9-45

27. Jäger R, Purpura M, Stone JD, Turner SM, Anzalone AJ, Eimerbrink MJ, Pane M, Amoruso A, Rowlands DS, Oliver JM (2016) Probiotic Streptococcus thermophilus FP4 and Bifidobacterium breve BR03 supplementation attenuates performance and range-of-motion decrements following muscle damaging exercise. Nutrients 8(10):642. https://doi.org/10.3390/ nu8100642

28. Nieman DC (1997) Risk of upper respiratory tract infection in athletes: an epidemiologic and immunologic perspective. J Athl Train 32(4):344-349

29. West NP, Horn PL, Pyne DB, Gebski VJ, Lahtinen SJ, Fricker PA, Cripps AW (2014) Probiotic supplementation for respiratory and gastrointestinal illness symptoms in healthy physically active individuals. Clin Nutr 33:581-587. https://doi.org/10.1016/j.clnu.2013. 10.002

30. Windy K, De Preter V, Verbeke K (2011) Relevance of protein fermentation to gut health. Mol Nutr Food Res 56(1):184-196. https://doi.org/10.1002/mnfr.201100542

Publisher's Note Springer Nature remains neutral with regard to jurisdictional claims in published maps and institutional affiliations. 